\title{
Chemical Attributes of Soil and Forage Yield of Pasture Recovered with Phosphate Fertilization and Soil Management
}

\author{
M. D. Rebonatti, C. E. Fabrice, J. M. F. Santos, R. Heinrichs, C. V. Soares Filho \&
}

A. Moreira

To cite this article: M. D. Rebonatti, C. E. Fabrice, J. M. F. Santos, R. Heinrichs, C. V. Soares Filho \& A. Moreira (2016) Chemical Attributes of Soil and Forage Yield of Pasture Recovered with Phosphate Fertilization and Soil Management, Communications in Soil Science and Plant Analysis, 47:18, 2069-2076, DOI: 10.1080/00103624.2016.1228939

To link to this article: https://doi.org/10.1080/00103624.2016.1228939

Sep 2016.

Published online: 16 Sep 2016.

Submit your article to this journal $\pi$

山 Article views: 76

View related articles

View Crossmark data $\nearrow$ 


\title{
Chemical Attributes of Soil and Forage Yield of Pasture Recovered with Phosphate Fertilization and Soil Management
}

\author{
M. D. Rebonattia , C. E. Fabrice ${ }^{\text {, }}$, J. M. F. Santos ${ }^{a}$, R. Heinrichs ${ }^{a}$, C. V. Soares Filhob ${ }^{\text {, }}$ \\ and A. Moreirac \\ aDepartment of Animal Science, São Paulo State University (UNESP), Campus of Dracena, Dracena, São Paulo, Brazil; \\ bDepartment of Animal Science, São Paulo State University (UNESP), Campus of Araçatuba, Araçatuba, São Paulo, \\ Brazil; 'Department of Soil Science, National Soybean Research Center of EMBRAPA, Londrina, Paraná State, Brazil
}

\begin{abstract}
Extensive and semi-extensive pastures are the basis of Brazilian livestock production. However, much of it is degraded or in degradation process, with low stocking rate per area. Even with this problem, this management type is $60 \%$ and $50 \%$ of Australia's and the United States' production costs, respectively. In order to research alternatives for Urochloa decumbens degraded pasture recovery in an Oxisol, Stylosanthes (Stylosanthes spp.) "Campo Grande" cultivar was introduced and phosphate fertilization was applied. The experimental design was of randomized blocks, $7 \times 2 \times 2$ factorial design, with four replicates, involving seven systems to introduction $\left(U\right.$. decumbens control; partial desiccation with $1.5 \mathrm{~L} \mathrm{ha}^{-1}$ glyphosate, total desiccation with $3.0 \mathrm{~L} \mathrm{ha}^{-1}$ glyphosate; direct planting; scarification, harrowing, and plowing + harrowing), phosphate fertilizer presence or absence, and two evaluation periods. "Campo Grande" Stylosanthes legume introduction increased shoot dry weight (SDW) yield, except in direct planting. Phosphorus fertilization increased SDW yield only in the first period, and Stylosanthes introduction in the pasture has not changed soil chemical properties. Phosphorus (P) fertilization also provided available $\mathrm{P}$ and exchangeable calcium $\left(\mathrm{Ca}^{2+}\right)$ content in the soil increase, in addition to sum of bases and cation exchange capacity increase.
\end{abstract}

\section{ARTICLE HISTORY}

Received 15 October 2015

Accepted 24 June 2016

\section{KEYWORDS}

Forage yield; soil fertility; Stylosanthes; Urochloa decumbens

\section{Introduction}

Livestock production extractive form is increasing degraded (or in degradation process) pasture areas, leading to a sharp productivity and meat production drop. Soil fertility depletion due to fertilization absence has been implicated as one of the major causes of this scenario (Bonfim-da-Silva and Monteiro 2006). In this sense, intercropping between grasses and legumes has been highlighted, combined with direct planting, desiccation, scarification, and minimum preparation practices.

Nitrogen $(\mathrm{N})$ fixation is one of the most important $\mathrm{N}$ sources in the agricultural system. The most important $\mathrm{N}$ fixation agents are symbiotic associations between legumes and Rhizobium genus bacteria (Andrews et al. 2009; Fustec et al. 2010). Forage legumes contribute to soil fertility improvement and increased forage yield, as they are able to fix large $\mathrm{N}$ amounts. $\mathrm{N}$ fertilization, in addition to high cost, also requires frequent fertilization. However, $\mathrm{N}$ has to be always replaced, as it is the element required in the largest quantity, being the major responsible for forage productivity. Therefore, it is very important to seek alternatives, such as intercropping, and develop soil and pasture management methods, in order to allow for

CONTACT A. Moreira adonismoreira66@gmail.com Embrapa Soybean, Rodovia Carlos João Strass, Acesso Orlando Amaral, s/n, Distrito de Warta, Londrina 86001-970, Parana State, Brazil.

Color versions of one or more of the figures in the article can be found online at www.tandfonline.com/lcss. 
proper system maintenance; moreover, the tropical legume species are more adapted to low fertility and soil acidity conditions (Werner et al. 1996).

The Urochloa decumbens yield increases in "Campo Grande" Stylosanthes intercropped areas surpass those of single crop areas, without fertilization, from the second cultivation year. This is due to organic matter $(\mathrm{OM})$ mineralization, generating soil $\mathrm{N}$ increases in the order of $60-80 \mathrm{~kg} \mathrm{ha}^{-1}$ year $^{-1}$ (Fernandes et al. 2005). Therefore, the aim of this study was to evaluate forage shoot dry weight (SDW) yield and soil chemical properties in U. decumbens "Basilisk" cv. degraded pasture recovery, with "Campo Grande" Stylosanthes implantation forms and P fertilization.

\section{Material and methods}

The study was conducted in Andradina County, São Paulo State, Brazil, 379 m of altitude, $20^{\circ} 55^{\prime}$ LS and $51^{\circ} 23^{\prime} \mathrm{LW}$, during the period from February 2011 to June 2013. Experiment implementation occurred in February 2011; in April, standardization harvest was performed. From November of that year, when $U$. decumbens reached cutting height, until June of 2013, analyses were performed, which were divided into two experimental periods: November 2011 to June 2012 (first period-2011/2012), and December 2012 to June 2013 (second period-2012/2013).

Climate, according to Köppen classification, is of Aw type, characterized by hot and humid summer seasons, and warm and dry winters, with higher rainfall between November and March. The average annual temperature and rainfall are, respectively, $23^{\circ} \mathrm{C}$ and $1,150 \mathrm{~mm}$. Climate data relating to rainfall $(\mathrm{mm})$, minimum mean temperatures $\left({ }^{\circ} \mathrm{C}\right)$, and maximum averages $\left({ }^{\circ} \mathrm{C}\right)$ during the experimental period are presented in Figure 1.

The soil of experimental area was an Oxisol, medium texture (EMBRAPA 2006). During experiment, soil samples were collected at $0-20 \mathrm{~cm}$ depth, having the following chemical and physical attributes (Raij, Andrade, and Cantarella 2001): $\mathrm{pH}\left(\mathrm{CaCl}_{2}\right)=4.5$, organic matter $(\mathrm{OM})=21.5 \mathrm{~g} \mathrm{~kg}^{-1}$, available phosphorus $(\mathrm{P})=3.5 \mathrm{mg} \mathrm{kg}^{-1}$ (resin extractant), available sulfur $\left(\mathrm{S}_{-} \mathrm{SO}_{4}{ }^{2-}\right)=11.0 \mathrm{mg} \mathrm{kg}^{-1}$, exchangeable potassium $\left(\mathrm{K}^{+}\right)=4.6 \mathrm{mmol}_{\mathrm{c}} \mathrm{dm}^{-3}$, exchangeable calcium $\left(\mathrm{Ca}^{2+}\right)=18 \mathrm{mmol}_{\mathrm{c}} \mathrm{kg}^{-1}$, exchangeable magnesium $\left(\mathrm{Mg}^{2+}\right)=7.5 \mathrm{mmol}_{\mathrm{c}} \mathrm{kg}^{-1}$, cation exchange capacity $(\mathrm{CEC})=53.6 \mathrm{mmol}_{\mathrm{c}} \mathrm{kg}^{-1}$, base saturation $(\mathrm{V})=56 \%$, aluminum saturation $(\mathrm{m})=15.5 \%$, available boron $(\mathrm{B}$ - hot water $)=0.84 \mathrm{mg} \mathrm{kg}^{-1}$, available copper [Cu-diethylenetraminepentaacetic acid (DTPA)-triethanolamine (TEA) $]=0.80 \mathrm{mg} \mathrm{kg}^{-1}$, available iron $(\mathrm{Fe}-\mathrm{DTPA}-\mathrm{TEA})=53 \mathrm{mg} \mathrm{kg}{ }^{-1}$, available manganese $(\mathrm{Mn}-\mathrm{DTPA}-\mathrm{TEA})=13.25 \mathrm{mg} \mathrm{kg}{ }^{-1}$, $\mathrm{zinc}^{-}$ $(\mathrm{Zn}-\mathrm{DTPA}-\mathrm{TEA})=1.2 \mathrm{mg} \mathrm{kg}^{-1}$, sodium $(\mathrm{Na})=10.35 \mathrm{mg} \mathrm{dm}^{-1}$, electrical conductivity $(\mathrm{EC})=0.12 \mathrm{dS}$ $\mathrm{m}^{-1}$, clay $=170 \mathrm{~g} \mathrm{~kg}^{-1}$, silt $=60 \mathrm{~g} \mathrm{~kg}^{-1}$, and sand $=770 \mathrm{~g} \mathrm{~kg}^{-1}$.

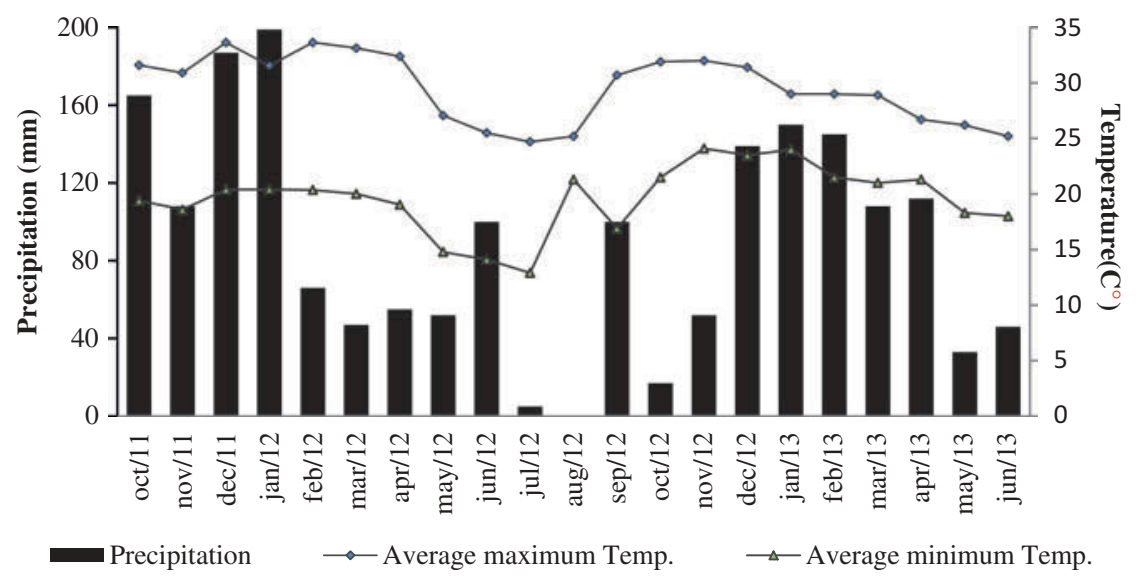

Figure 1. Precipitation and average minimum and maximum temperatures observed during trial period. Source: CIIAGRO (Agrometeorology Information Integrated Center). 
The experiment was installed on $02 / 02 / 2011$, in an area of $3,500 \mathrm{~m}^{2}$ with $U$. decumbens "Basilisk" cv. degraded pasture, established at about 10 years, with low yield and low invasive plant infestations. "Campo Grande" cv. (80\% Stylosanthes capitata and 20\% S. macrocephala) Stylosanthes legume was implanted, with different management systems and phosphate fertilization. The experimental design was a randomized block in $7 \times 2 \times 2$ factorial arrangement, involving seven Stylosanthes introduction systems, phosphate fertilizer (presence or absence), and two evaluation periods (2011/2012 and 2012/ 2013). Plot dimensions were $10 \mathrm{~m} \times 10 \mathrm{~m}$, with the following treatments: $U$. decumbens control (CB); direct planting with partial desiccation (1.5 $\mathrm{L} \mathrm{ha}^{-1}$ glyphosate) (PD); direct planting with complete desiccation (3.0 $\mathrm{L} \mathrm{ha}^{-1}$ glyphosate) (TD); direct planting without desiccation (DP); scarification (E); harrowing $(\mathrm{H})$, and plowing + harrowing $(\mathrm{PH})$. In $\mathrm{H}$ and $\mathrm{PH}$ treatments, Stylosanthes sowing was made through broadcast seeding. In the other treatments, sowing was made through direct sowing, with row sowing, except for the control treatment, which remained exclusively with $U$. decumbens.

Phosphate fertilization presence and absence were evaluated. The source used was single superphosphate (SSP-20\% $\mathrm{P}_{2} \mathrm{O}_{5}, 12 \% \mathrm{~S}$, and $\left.18 \% \mathrm{Ca}\right)$, at a rate of $60 \mathrm{ha}^{-1}$ year ${ }^{-1}$ phosphorus pentoxide $\left(\mathrm{P}_{2} \mathrm{O}_{5}\right)$, following the recommendation of Werner et al. (1996), being held at the time of the experiment implementation, in 2011/2012, and before rainy season start, in 2012/2013. In all plots, $20 \mathrm{~kg} \mathrm{ha}^{-1} \mathrm{~K}_{2} \mathrm{O}$ as potassium chloride $\left(\mathrm{KCl}-60 \% \mathrm{~K}_{2} \mathrm{O}\right)$ was applied. The legume was introduced with the sowing of $5.0 \mathrm{~kg} \mathrm{ha}^{-1}$ seeds, with cultural value of $92 \%$, through broadcast seeding in $\mathrm{H}$ and $\mathrm{PH}$ treatments, and through $0.22 \mathrm{~m}$ spaced rows in other treatments, on 02/07/2011.

In April 2011, treatments standardization cutting was conducted for better legume initial development and to homogenize all treatments. For statistical analysis purposes, the experiment was divided into two production cycles, following the crop year in the region. It consisted of six cuts in the first cycle (November, December, January, February, April, and May) and five cuts in the second (December, February, March, May, and June), due to rainy season delay observed in this agricultural year. Within each study period, cuts were further divided into seasons: spring/summer and fall; in winter, cuts were not made.

When pasture height reached $30 \mathrm{~cm}$, forage SDW was measured, with $1.0 \mathrm{~m}^{2}$, positioned in each treatment representative and random points. The grass was cut at $10 \mathrm{~cm}$ above the soil, obtaining green forage weight. In order to obtain the SDW, samples were dried in a forced-air oven, at $65{ }^{\circ} \mathrm{C}$, for $72 \mathrm{~h}$. Subsequently, they were weighed again, as described by Silva and Queiroz (2002). Field green weight values were converted into forage SDW ton per hectare. After each collection, experimental plots were grazed by up to 1 day and a half, by "Nelore" cattle occupation, keeping the $10 \mathrm{~cm}$ residue. At the end of each experiment evaluation period, soil was collected in five random points within each plot floor area, using probe type auger, $0-20 \mathrm{~cm}$ depth. Composite samples, originated from simple samples, were sent for chemical analysis, according to the methodology described by Raij, Andrade, and Cantarella (2001).

Data were analyzed for errors normality and variances homogeneity. Statistical analyses were performed using the SAS software (Statistical Analysis System 1999), for the factorial. Results were submitted to analysis of variance (ANOVA), F test, and Tukey's test, for means multiple comparison, at $5 \%$ probability level.

\section{Results and discussion}

Total SDW showed significant interaction between "Campo Grande" Stylosanthes introduction systems and evaluation periods (Table 1), and between phosphate fertilizer and evaluated periods (Table 1). There was no interaction between legume implantation methods and P fertilization. SDW ranged from 10.7 to $17.5 \mathrm{t} \mathrm{ha}^{-1}$ and from 8.2 to $11.8 \mathrm{t} \mathrm{ha}^{-1}$, in the first and second evaluation periods, respectively. In both periods, direct planting treatment had the lowest yield; harrowing preparation had the highest yield in 2011/2012; in 2012/2013, total desiccation treatment was superior. For all treatments, SDW yield was lower in the second period (Table 1), which may be 
Table 1. Urochloa decumbens intercropped with "Campo Grande" Stylosanthes legume introduction systems shoot dry weight (SDW) yield, with (+) and without (-) P fertilization.

\begin{tabular}{lcc}
\hline & \multicolumn{2}{c}{ SDW $\left(\mathrm{t} \mathrm{ha}^{-1}\right)$} \\
\cline { 2 - 3 } Treatments & $2011 / 2012$ & $2012 / 2013$ \\
\hline Control (U. decumbens) & $11.4 \mathrm{dA}$ & $8.4 \mathrm{cB}$ \\
Direct planting & $10.7 \mathrm{dA}$ & $8.2 \mathrm{cB}$ \\
Partial desiccation & $17.5 \mathrm{abA}$ & $11.0 \mathrm{abB}$ \\
Total desiccation & $15.8 \mathrm{bcA}$ & $11.8 \mathrm{aB}$ \\
Scarification & $14.0 \mathrm{cA}$ & $9.7 \mathrm{bcB}$ \\
Harrowing & $17.9 \mathrm{aA}$ & $11.1 \mathrm{abB}$ \\
Plowing+harrowing & $16.1 \mathrm{abA}$ & $10.4 \mathrm{abB}$ \\
$(-)$ P & $13.9 \mathrm{bA}$ & $9.9 \mathrm{aB}$ \\
$(+) \mathrm{P}$ & $15.5 \mathrm{aA}$ & $10.3 \mathrm{aB}$ \\
\hline
\end{tabular}

Note: Means followed by different lowercase letters in columns and uppercase in same lines differ at $5 \%$ probability by Tukey's test.

related to several factors. In the first period, six cuts were performed, while only five were made in the second period, due to rainy season delay (Figure 1); lower yield, including in the control treatment, is probably related to that.

Drop in yield was even more pronounced in partial desiccation, scarification, harrowing, and plowing + harrowing treatments. In these treatments, there was a good initial legume force, whose SDW yield was important to increase these treatments SDW yield. Total desiccation treatment was also improved, which had a lower relative drop from the first to the second period, continuing with great yield, being the best second period treatment. Aroeira et al. (2005) have also found lower SDW yield in $U$. decumbens and Stylosanthes intercropping during lower rainfall and low temperature periods. Other factors that may have contributed to increased yield in the first assessment year were legume initial force and soil disturbance, which was conducted in some treatments, accelerating OM mineralization.

Second period SDW yield variation was similar to that verified by Paciullo et al. (2003) on monocrop and intercropped $U$. decumbens grass, which received cumulative production in six cuts of 8.9 and $12.9 \mathrm{t} \mathrm{ha}^{-1}$, respectively. According to Nabinger (2001), yield increase can be explained by the fact that $\mathrm{N}$ acts as a controlling factor and promotes plant growth, which provides biomass increase by carbon fixation (C), especially in Stylosanthes case, which is a legume. Moreira et al. (2005) analyzed single $U$. decumbens pasture fertilized with $\mathrm{N}$ rates, or intercropped with Stylosanthes, without fertilization. Intercropping SDW was $9 \%$ higher than the single grass fertilized in the first cutting, when Stylosanthes represented $75 \%$ of the intercropped pasture. In the second cutting, this share dropped to $54 \%$, with consequent intercrop SDW drop, which was $18 \%$ lower than single fertilized grass maximum yield. These results show that intercrop SDW was increased by Stylosanthes, while the increase is due to grass higher yield in single U. decumbens.

With regard to phosphate fertilization, there was no interaction with legume introduction strategies. However, there was interaction with evaluation periods (Table 1). In 2011/2012, there was statistical difference between fertilized and non-fertilized, although yield increase was of only $11 \%$ in fertilized plots; in 2012/2013, there was no significant fertilization effect, even with increase of available P content in the soil (Table 3). Lopes et al. (2011), while evaluating "Xaraés" grass and Stylosanthes intercropping, obtained grass SDW yield increasing response in function of $\mathrm{P}$ rates during the first dry season, after pasture establishment. Moreira et al. (2010) also found positive effect of phosphate fertilization on Megathirsus maximum "Massai" cv. in SDW yield.

Analyzing the two evaluation periods SDW yield (Figure 2), significant difference was observed between legume introduction systems. Total desiccation, partial desiccation, harrowing, and plowing + harrowing treatments stood out, with average period yields above $13 \mathrm{t} \mathrm{ha}^{-1}$; in turn, the lowest average was at direct planting, followed by control treatment, with average yields below $10 \mathrm{tha}^{-1}$. In direct planting treatment, Stylosanthes seeds were directly sown in the pasture and germination was 


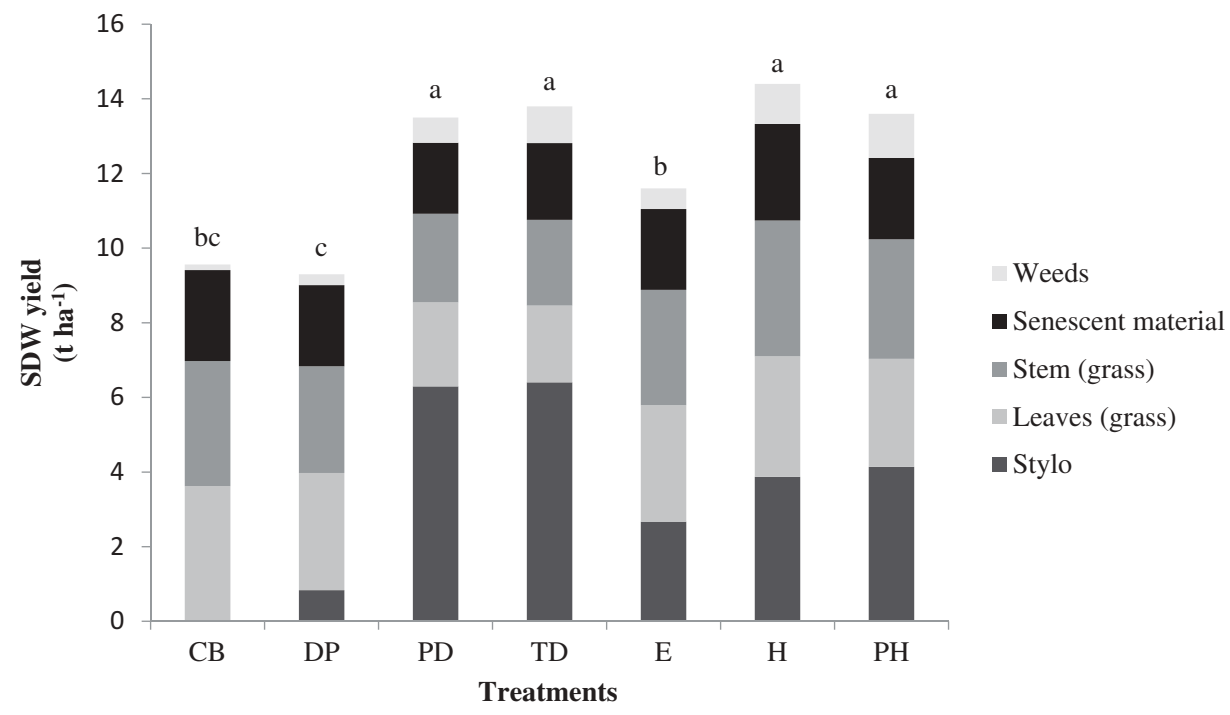

Figure 2. Shoot dry weight (SDW) yield as a function of "Campo Grande" Stylosanthes introduction systems. Different lowercase letters in columns differ at $5 \%$ probability by Tukey's test. (CB-U. decumbens control; PD—partial desiccation; TD—total desiccation; $\mathrm{DP}$ - direct planting; $\mathrm{E}$ - scarification; $\mathrm{H}$-harrowing; $\mathrm{PH}$ - plowing + harrowing). Average of two evaluation periods.

very low, with seedlings being stifled by the already developed grass. Therefore, this treatment showed very low legume participation, with a similar result to that seen in the control treatment, showing $U$. decumbens suppressive effect on legume development.

Treatments with desiccation and soil disturbance favored legume development, whose SDW yield significantly contributed to increase in forage total yield. In harrowing and plowing + harrowing treatments, soil disturbance may have favored nutrient cycling and their plant availability, as well as in desiccation treatments, both total and partial, by plant residues mineral decomposition. Michalk, Nan-Ping, and Chin-Ming (1998) obtained similar results and better establishment yield for Stylosanthes cultivars and grasses seeded in native pasture, under tillage methods. According to the authors, plowing and harrowing total tillage favors Stylosanthes plants density. P application minimal preparation provides the most appropriate intercrop establishment. For soil chemical properties, there was no significance between legume introduction systems. However, there were evaluated periods and $\mathrm{P}$ fertilization isolated effects (Table 2), with $\mathrm{OM}, \mathrm{K}^{+}, \mathrm{Mg}^{2+}$, available $\mathrm{Cu}$, and available $\mathrm{Mn}$ increase in the second assessment year; as well as increased soil $\mathrm{pH}$ and CEC.

With regard to phosphate fertilization (Table 2), there was positive response for phosphorus and calcium contents, as well as CEC increase. OM content only responded to the assessment period,

Table 2. Soil chemical attributes during two evaluation periods, with (+) and without (-) P fertilization on Urochloa decumbens intercropped with "Campo Grande" Stylosanthes.

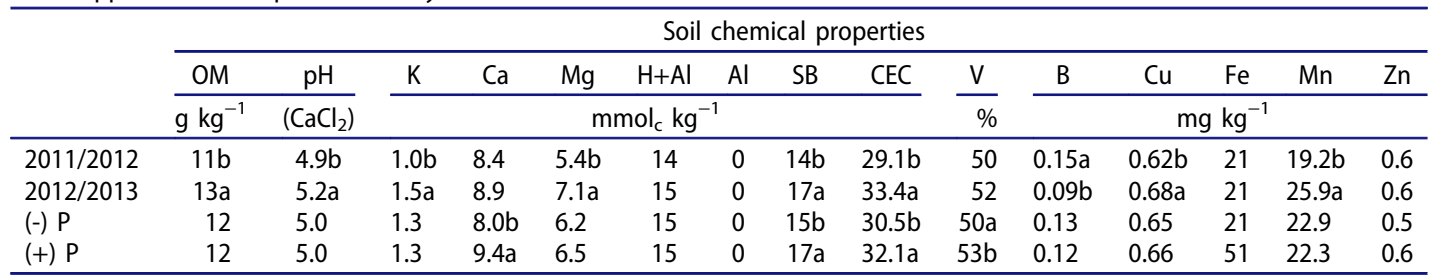

Notes: Means followed by different lowercase letters in columns differ at 5\% probability by Tukey's test. SB-sum of bases, CECcation exchange capacity $(\Sigma \mathrm{K}, \mathrm{Ca}, \mathrm{Mg}, \mathrm{H}+\mathrm{Al}), \mathrm{V}$-base saturation. 
ranging from 11.0 to $13.0 \mathrm{mg} \mathrm{kg}$. That is, $18 \%$ increase in $2012 / 2013$ (Table 2), which is an important result to explain pasture nutrient cycling, since nutrient content increase can be explained by soil OM increase. Furthermore, it is known that in tropical soils, especially Oxisol with high weathering degree, dominant minerals (kaolinite, oxides, and iron $\left(\mathrm{Fe}^{2+}\right)$ and aluminum $\left(\mathrm{Al}^{3+}\right)$ hydroxides) surface charge is very weak. Thus, soil OM plays a preponderant role, contributing to specific surface, CEC, and soil cation adsorption increase (Santos et al. 2012).

There was $\mathrm{pH}$ value increase, from 4.9 to 5.2, from the first to the second period (Table 2). It is likely that $\mathrm{pH}$ increase is related to OM positive effect in the soil, which helps increasing CEC and sum of bases (SB) $\left(\Sigma \mathrm{K}^{+}, \mathrm{Ca}^{2+}, \mathrm{Mg}^{2+}, \mathrm{Na}^{+}\right)$. Noble et al. (2002), while studying different legumes cultivation, found that areas managed under Stylosanthes induced soil acidification, showing distinct dynamics existence as a function of management, soil conditions, climate, and involved plant species.

In the soil, the $\mathrm{K}^{+}$content only responded to the analyzed periods, observing a $50 \%$ increase in 2012/2013 (1.0 to $1.5 \mathrm{mmol}_{\mathrm{c}} \mathrm{kg}^{-1}$ ) (Table 2). Possibly, the increase is not only related to $\mathrm{K}$ fertilization maintenance, but also to higher nutrient cycling and soil OM content increase. In addition to contributing to $\mathrm{K}$ supply, they increase this element retention, reducing leaching losses. Raij et al. (1997) and Pacheco et al. (2011) reported grasses efficiency in recycling this nutrient in the soil surface layer. Werner et al. (1996) reported those values between 0.8 and $1.5 \mathrm{mmol}_{\mathrm{c}} \mathrm{kg}^{-1} \mathrm{~K}^{+}$lie in the same interpretation range, being considered low.

Exchangeable $\mathrm{Ca}^{2+}$ content was not influenced by evaluation periods (Table 2). However, there was a $17 \%$ increase when phosphate fertilization was performed (Table 2), which is an effect that can be attributed to the source used, as SSP has approximately $20 \% \mathrm{Ca}$ in its composition. Contents ranged from 8.4 to 8.9 , from $2011 / 2012$ to 2012/2013, and from 8.0 to 9.4, in treatments with and without $\mathrm{P}$ fertilization; values above $7.0 \mathrm{mmol}_{\mathrm{c}} \mathrm{kg}^{-1}$ of $\mathrm{Ca}^{2+}$ are considered high by Werner et al. (1996). Soil Mg only responded to the assessed period, with $31 \%$ increase in the second period (5.4$7.1 \mathrm{mmol}_{\mathrm{c}} \mathrm{kg}^{-1}$, in 2011/2012 and 2012/2013, respectively) (Table 2), being due to CEC, $\mathrm{pH}$, and soil $\mathrm{OM}$ content increase. Although significant, this difference does not affect the interpretation range of 5.0 to $8.0 \mathrm{mmol}_{\mathrm{c}} \mathrm{kg}^{-1}$ of $\mathrm{Mg}^{2+}$, classified by Werner et al. (1996) as average content.

Potential acidity [hydrogen $\left(\mathrm{H}^{+}\right)+\mathrm{Al}^{3+}$ ] showed no significant difference between evaluation periods or phosphate fertilization, remaining in the $14.0-15.0 \mathrm{mmol}_{\mathrm{c}} \mathrm{kg}^{-1}$ range. SB remained between 14.0 and $17.0 \mathrm{mmol}_{\mathrm{c}} \mathrm{kg}^{-1}$ in the first and second periods, respectively, accompanying $\mathrm{K}^{+}$and $\mathrm{Ca}^{2+}$ content increase (Table 2). There was also SB increase in $\mathrm{P}$ presence in treatments that received phosphate fertilizer $\left(15.0-17.0 \mathrm{mmol}_{\mathrm{c}} \mathrm{dm}^{-3}\right)$, with the same effect on $\mathrm{Ca}^{2+}$ content (Table 2). SSP has $18-20 \% \mathrm{Ca}$ in its composition. CEC responded to evaluation periods and phosphate fertilization (Table 2) isolate. CEC value increase of $15.0 \%$ was observed in the second assessed year; for phosphate fertilization, the increase was more discreet, 5.0\%. CEC increases with increasing OM content, giving the soil higher exchangeable cations adsorption, released by OM decomposition. Base saturation (V) has not responded differently to assessed periods and fertilization, remaining constant (Table 2).

Soil micronutrients only responded to assessed periods (Table 2). Available B content decreased $40 \%$, from 0.15 to $0.09 \mathrm{mg} \mathrm{kg}^{-1}$, not following soil OM increase, which may be attributed to nutrient leaching. In addition, it can also be attributed to experimental variation, since both values are in the interpreting range considered low (Werner et al. 1996). Available $\mathrm{Cu}$ increased by almost $10 \%$ in the second period, with statistically significant difference, while Mn had an increase of 35\% (19.2$25.9 \mathrm{mg} \mathrm{kg}^{-1}$ ), with values considered high.

Available $\mathrm{Fe}$ and $\mathrm{Zn}$ contents in the soil have not changed during the study period, and were not affected by phosphate fertilization (Table 2). According to Consolini and Coutinho (2004), Zn soil availability and crop uptake decreased with increasing soil $\mathrm{pH}$. However, available $\mathrm{Zn}$ was not correlated with $\mathrm{pH}$ in this study, possibly due to soil acidity variation being not enough to affect micronutrient availability. It is noteworthy that $\mathrm{Zn}$ is one of the most limiting micronutrients for "Cerrado" soils agricultural use (Fageria and Moreira 2014; Vendrame et al. 2007).

From these figures, it is possible to observe that although available $\mathrm{B}, \mathrm{Cu}$, and $\mathrm{Mn}$ have shown significant differences, they remained within the same interpretation range described by Werner 
Table 3. Available phosphorus (P) in soil during two consecutive years, with $(+)$ and without $(-) \mathrm{P}$ fertilization on Urochloa decumbens intercropped with "Campo Grande" Stylosanthes.

\begin{tabular}{|c|c|c|}
\hline \multirow[b]{3}{*}{ Evaluation periods } & \multicolumn{2}{|c|}{ P fertilization } \\
\hline & $(-) P$ & $(+) P$ \\
\hline & \multicolumn{2}{|c|}{$\mathrm{P}\left(\mathrm{mg} \mathrm{kg}^{-1}\right)$} \\
\hline $2011 / 2012$ & $1.8 \mathrm{bA}$ & $2.4 \mathrm{bA}$ \\
\hline $2012 / 2013$ & $2.9 \mathrm{aB}$ & $8.0 \mathrm{aA}$ \\
\hline
\end{tabular}

Means followed by different lowercase letters in columns and uppercases in same lines differ at $5 \%$ probability by Tukey's test.

et al. (1996), being low for available $\mathrm{B}$ and $\mathrm{Zn}$, medium for available $\mathrm{Cu}$, and high for available Fe and $\mathrm{Mn}$. The same tendency was observed in available $\mathrm{P}$ and exchangeable $\mathrm{K}, \mathrm{Ca}$, and $\mathrm{Mg}$ contents in the soil. Comparing initial soil analysis (prior to experiment setup) and evaluated period results, it can be inferred that, in general, change in treatment application soil chemical attributes was subtle. i.e., soil fertility was maintained, without large increases or losses.

Positive interaction between evaluation periods and phosphate fertilization was observed in soil available P content (Table 3), which increased with time and with fertilization. In 2011/2012, no significant soil P content increase was observed, which varied between 1.8 and $2.4 \mathrm{mg} \mathrm{kg}^{-1}$. In 2012 / 2013, available $P$ content increased compared to the previous year, including the plots that received no fertilization. However, the most significant difference is in the phosphorus content of plots that received the fertilizer, $175 \%$ higher compared to non-fertilized plots, and $233 \%$ higher compared to the same plots in the previous year. It is also noteworthy that there was no difference between treatments, i.e., treatments in which there was no $\mathrm{P}$ incorporation $(\mathrm{CB}, \mathrm{PD}, \mathrm{TD}$, and $\mathrm{DP}$ ) were similar to those in which there was incorporation $(\mathrm{H}, \mathrm{P}+\mathrm{H}$, and $\mathrm{E})$. Established pasture cover phosphorus fertilization efficiency is discussed in intensive yield systems, given low soil P mobility. Canto et al. (2003) observed SDW yield increase in oat (Avena sativa L.) tillering when incorporating fertilizer. Ieiri et al. (2010) obtained higher SDW yield when triple superphosphate $\left(41 \% \mathrm{P}_{2} \mathrm{O}_{5}, 13 \% \mathrm{Ca}\right)$ incorporation was not carried out in Urochloa sp.

\section{Conclusions}

In Brazil, most soils are characterized by low content of available P and high acidity. Considering that this nutrient acts on root development and grasses tillering, its lack significantly reduces early growth rate and forage establishment. Studies on its use at adequate levels are needed. So do studies on legume introduction, which, in addition to increasing soil $\mathrm{N}$ content and nutrients $\left(\mathrm{P}, \mathrm{K}^{+}, \mathrm{Ca}^{2+}, \mathrm{Mg}^{2+}, \mathrm{B}, \mathrm{Cu}, \mathrm{Fe}\right.$, $\mathrm{Mn}$, and $\mathrm{Zn}$ ), is a protein source for animals. The introduction of Stylosanthes, cultivar "Campo Grande" provides pasture recovery, with increased SDW yield, except in direct planting. Phosphate fertilization increased SDW yield in the first period only. Stylosanthes pasture implementation has not changed soil chemical properties $(0-20 \mathrm{~cm}$ depth). Phosphate fertilization gave increased available $\mathrm{P}$ and exchangeable $\mathrm{Ca}^{2+}$ content in the soil, in addition to increased SB and CEC.

\section{Funding}

The Research Support Foundation of São Paulo (FAPESP) provided scholarship to the first author, and project execution assistance.

\section{References}

Andrews, M., P. J. Lea, J. A. Raven, and R. A. Azevedo. 2009. Nitrogen use efficiency: Nitrogen fixation: Genes and costs. Annual Applied of Biology 155:1-13. doi:10.1111/j.1744-7348.2009.00338.x. 
Aroeira, L. J. M., D. S. C. Paciullo, F. C. F. Lopes, M. J. F. Morenz, E. S. Saliba, J. J. Silva, and C. Ducatti. 2005. Herbage availability, chemical composition and dry matter intake in mixed pasture of Brachiaria decumbens with Stylosanthes guianensis. Pesquisa Agropecuária Brasileira 40:413-18.

Bonfim-da-Silva, E. M., and F. A. Monteiro. 2006. Nitrogen and sulphur for productive characteristics of signal grass from degrading pasture area. Revista Brasileira De Zootecnia 35:1289-97.

Canto, M. W., M. Y. S. M. Lima, E. Sengik, and M. E. Rickli. 2003. Effect of different incorporation depths of phosphate fertilization on the yield of dry matter and tillering of black oat (Avena strigosa Schreb). Acta Scientiarum 25:359-63.

Consolini, F., and E. L. M. Coutinho. 2004. Effects of Zn application and soil pH on micronutrient availability. Acta Scientiarum 26:7-12.

EMBRAPA (Empresa Brasileira de Pesquisa Agropecuária). 2006. Brazilian system of soil classification. Rio de Janeiro, Brazil: Embrapa Soils.

Fageria, N. K., and A. Moreira. 2014. Zinc-use efficiency in upland rice genotypes. Communications in Soil Science Plant Analysis 46:94-108. doi:10.1080/00103624.2014.956889.

Fernandes, C. D., B. Grof, S. Chakraborty, and J. R. Verzignassi. 2005. Estilosantes Campo Grande in Brazil: A tropical forage legume success story. Tropical Grassland 39:223-24.

Fustec, J., F. Lesuffleur, S. Mahieu, and J. B. Cliquet. 2010. Nitrogen rhizodeposition of legumes: A review. Agronomy for Sustainable Development 30:57-66. doi:10.1051/agro/2009003.

Ieiri, A. Y., R. M. Q. Lana, G. H. Korndorfer, and H. S. Pereira. 2010. Sources, doses, and application method of phosphorus in the recovery of Brachiaria pasture. Ciência E Agrotecnologia 34:1154-60. doi:10.1590/S1413-70542010000500011.

Lopes, J., A. R. Evangelista, J. C. Pinto, D. S. Queiroz, and J. A. Muniz. 2011. Phosphorus rates in the establishment of intercropping of Xaraés grass and Mineirão Stylosanthes. Revista Brasileira De Zootecnia 40:2658-65.

Michalk, D. L., F. Nan-Ping, and Z. Chin-Ming. 1998. Improvement of dry tropical rangelands on Hainan Island, China: 4. Effect of seedbed on pasture establishment. Journal of Range Management Archives 51:106-14. doi:10.2307/4003572.

Moreira, A., N. K. Fageria, G. B. Souza, and A. R. F. Freitas. 2010. Production, nutritional status and chemical properties of soil with addition of cattle manure, reactive natural phosphate and biotite schiste in Massai cultivar. Revista Brasileira De Zootecnia 39:1883-88. doi:10.1590/S1516-35982010000900004.

Moreira, L. M., D. M. Fonseca, C. M. T. Vítor, A. J. Assis, D. Nascimento Júnior, J. I. Ribeiro Júnior, and J. A. Obeid. 2005. Renewing the degraded Melinis minutiflora pasture by introduction of tropical forages fertilized with nitrogen or under mixture cropping system. Revista Brasileira De Zootecnia 34:442-53. doi:10.1590/S1516-35982005000200011.

Nabinger, C. 2001. Management of defoliation. In Symposium of pasture management, org. ESALQ, $192-210$. Piracicaba, Brazil: ESALQ.

Noble, A. D., C. Middleton, P. N. Nelson, and L. G. Rogers. 2002. Risk mapping of soil acidification under Stylosanthes in northern Australian rangelands. Australian Journal of Soil Research 40:257-67. doi:10.1071/SR01018.

Pacheco, L. P., W. M. Leandro, P. L. O. A. Machado, R. L. Assis, T. Cobucci, B. E. Madari, and F. A. Petter. 2011. Biomass production and nutrient accumulation and release by cover crops in the off-season. Pesquisa Agropecuária Brasileira 46:17-25. doi:10.1590/S0100-204X2011000100003.

Paciullo, D. S. C., L. J. M. Aroeira, M. J. Alvim, and M. M. Carvalho. 2003. Productive and qualitative traits of Brachiaria decumbens pasture in monoculture and associated with Stylosanthes guianensis. Pesquisa Agropecuária Brasileira 38:421-26.

Raij, B., J. C. Andrade, and H. Cantarella. 2001. Chemical analysis to evaluate the fertility of tropical soils. Campinas, Brazil: Instituto Agronômico de Campinas.

Raij, B., H. Cantarella, J. A. Quaggio, and A. M. C. Furlani. 1997. Fertilization and liming recommendation to São Paulo State. Campinas, Brazil: Instituto Agronômico de Campinas.

Santos, G. G., P. M. Silveira, R. L. Marchao, F. A. Petter, and T. Becquer. 2012. Chemical properties and aggregate stability under different cover crops in Cerrado Oxisol. Revista Brasileira De Engenharia Agrícola E Ambiental 16:1171-78. doi:10.1590/S1415-43662012001100005.

SAS (Statistical Analysis System Institute. SAS/STAT). 1999. Procedure guide personal computers, 9th ed. Cary: NC Institute.

Silva, D. J., and A. C. Queiroz. 2002. Food analysis: Chemical and biological. Viçosa, Brazil: Federal University of Viçosa.

Vendrame, P. R. S., O. R. Brito, C. Quantin, and T. Becquer. 2007. Availability of copper, iron, manganese and zinc in soils under pastures in the Brazilian Cerrado. Pesquisa Agropecuária Brasileira 42:859-64.

Werner, J. C., V. T. Paulino, H. Cantarella, N. O. Andrade, and J. A. Quaggio. 1996. Forage. In Fertilization and liming recommendation to São Paulo State, eds. B. Raij, H. Cantarella, J. A. Quaggio, and A. M. C. Furlani., 263-73. Campinas, Brazil: Instituto Agronômico de Campinas. 